\title{
Adolescence, Adulthood and Self-Perceived Halitosis: A Role of Psychological Factors
}

\author{
Carmela Mento ${ }^{1, *(\mathbb{D}}$, Clara Lombardo ${ }^{2}$, Mariacristina Milazzo ${ }^{2}$, Nicholas Ian Whithorn ${ }^{3}$, \\ Montserrat Boronat-Catalá ${ }^{4}$, Pedro J. Almiñana-Pastor ${ }^{4}$, Cristina Sala Fernàndez ${ }^{1}$, Antonio Bruno ${ }^{1}(1)$, \\ Maria Rosaria Anna Muscatello ${ }^{1}\left[{ }^{1}\right.$ and Rocco Antonio Zoccali ${ }^{1}$
}

check for updates

Citation: Mento, C.; Lombardo, C.; Milazzo, M.; Whithorn, N.I.;

Boronat-Catalá, M.; Almiñana-Pastor,

P.J.; Fernàndez, C.S.; Bruno, A.;

Muscatello, M.R.A.; Zoccali, R.A.

Adolescence, Adulthood and Self-Perceived Halitosis: A Role of Psychological Factors. Medicina 2021, 57, 614. https://doi.org/10.3390/ medicina57060614

Academic Editor: Vita Maciulskiene

Received: 12 May 2021

Accepted: 10 June 2021

Published: 12 June 2021

Publisher's Note: MDPI stays neutral with regard to jurisdictional claims in published maps and institutional affiliations.

Copyright: (c) 2021 by the authors. Licensee MDPI, Basel, Switzerland. This article is an open access article distributed under the terms and conditions of the Creative Commons Attribution (CC BY) license (https:// creativecommons.org/licenses/by/ $4.0 /)$.
1 Department of Biomedical, Dental Sciences and Morphofunctional Imaging, University of Messina, Psychiatric Unit Policlinico “G. Martino” Hospital, 98124 Messina, Italy; csalafernandez@gmail.com (C.S.F.); antonio.bruno@unime.it (A.B.) mmuscatello@unime.it (M.R.A.M.); rocco.zoccali@unime.it (R.A.Z.)

2 Psychiatric Unit, Policlinico Hospital “G. Martino”, 98124 Messina, Italy; clara.lombardo1988@gmail.com (C.L.); Mary-cry13@hotmail.it (M.M.)

3 Department of Political Sciences, University of Messina, 98122 Messina, Italy; nwhithorn@yahoo.it

4 Department of Stomatology, Faculty of Medicine and Dentistry, University of Valencia, 46010 Valencia, Spain; montse_boronat@hotmail.com (M.B.-C.); pedroalminana@gmail.com (P.J.A.-P.)

* Correspondence: cmento@unime.it

\begin{abstract}
Background: Halitosis is a frequent condition that affects a large part of the population. It is considered a "social stigma", as it can determine a number of psychological and relationship consequences that affect people's lives. The purpose of this review is to examine the role of psychological factors in the condition of self-perceived halitosis in adolescent subjects and adulthood. (2) Type of studies reviewed: We conducted, by the PRISMA (Preferred Reporting Items for Systematic Review and Meta-Analyses) guidelines, systematic research of the literature on PubMed and Scholar. The key terms used were halitosis, halitosis self-perception, psychological factors, breath odor and two terms related to socio-relational consequences ("Halitosis and Social Relationship" OR "Social Issue of Halitosis"). Initial research identified 3008 articles. As a result of the inclusion and exclusion criteria, the number of publications was reduced to 38. (3) Results: According to the literature examined, halitosis is a condition that is rarely self-perceived. In general, women have a greater ability to recognize it than men. Several factors can affect the perception of the dental condition, such as socioeconomic status, emotional state and body image. (4) Conclusion and practical implication: Self-perceived halitosis could have a significant impact on the patient's quality of life. Among the most frequent consequences are found anxiety, reduced levels of self-esteem, misinterpretation of other people's attitudes and embarrassment and relational discomfort that often result in social isolation.
\end{abstract}

Keywords: self-perceived halitosis; psychological factors; breath odor; halitosis and social relationship

\section{Introduction}

Halitosis, commonly called bad breath, is a problem that can affect both the external, relational, social communication and internal, psychological sphere, with implications on perceived quality of life [1]. People are usually unaware of their breath, and when they become aware of it, they incorrectly attribute the cause of their condition. Halitosis is a frequent condition, present in $50-65 \%$ of the world population [2]. Although it is a significant source of discomfort, a precise estimation of prevalence is not possible because epidemiological studies are limited. This limitation could be determined by several factors, such as the absence of a standardized method for assessment of the disease, the difficulty in recognizing its presence and the likelihood that it is in some cases transient, which is why it is underreported in epidemiological data [3]. The problem of people with halitosis is that this condition can often remain unnoticed because people are generally unaware of the quality of their oral odor. Research conducted on Korean adolescent subjects [4] has made 
it possible to identify a considerable number of adolescents between 12 and 18 years of age with halitosis, highlighting the contributing factors at this age such as substance abuse and smoking, diet and economic social status. Regarding gender, there appears to be no correlation whatsoever $[5,6]$. The term physiological or transient halitosis refers to dental bad smell, which occurs only at certain times of the day, for example during the early morning hours. Occurring in the absence of a specific dental pathology, it can be associated with factors such as diet and tobacco use [3]; psychiatric illnesses, anxiety, depression and stress are also among the causes of halitosis [4-7]. Halitophobia or pseudohalitosis refers to the fear of suffering from bad breath. In such subjects, treatments aimed at resolving the bad smell would be useless, and evaluation and intervention of a psychologist [8] are considered appropriate. Pathological halitosis is divided by some authors into intraoral $(90 \%)$ and extraoral $(10 \%)$ halitosis [1]. The back of the tongue is a potential reservoir of bacteria and source of foul-smelling gases; therefore, daily washing should be performed to reduce the number of bacteria and the processes leading to the manifestation of foul smells [9-12]. Extraoral factors not related to the oral cavity include intake of maltogenic foods (such as garlic, onions, fatty foods, sugars and sweets, which can promote the development of caries and the production of substances with an unpleasant smell), smoking and alcohol, coffee abuse, metabolic disorders (such as liver failure, diabetic ketoacidosis, cirrhosis, renal failure, hiatal hernia), upper respiratory tract disorders (chronic sinusitis, nasal obstruction, nasopharyngeal abscess) and lower respiratory tract disorders (i.e., bronchitis, pulmonary abscess, lung cancer) [3-13]. Studies in the literature allow us to identify how halitosis has a significant impact on the life of the individual. Among the first consequences, it can cause embarrassment and depression [14,15]. In adolescence, it is a significant condition that compromises social development [16]. Considered by Kolo [5] as a "social stigma", it could become an obsession that dominates a person's life, determining the onset of factors such as anxiety and psychosocial stress. The hypochondria of some individuals can, in certain cases, determine the onset of what is called "delusional halitosis", caused by an incorrect assessment of their olfactory perceptions. The first factor to be compressed in subjects with halitosis is the communicative act with consequent impairment of professional interactions [17]. This could negatively affect self-esteem and confidence, reducing quality of life to the point of complete isolation [18]. Awareness of halitosis leads the individual to experience the condition negatively so that it leads to halitophobia, a term used to indicate a condition characterized by excessive concern with the belief of having halitosis [19]. One theme of studies on self-perceived halitosis shows that the problem is often not self-perceived [20,21]. Self-reported halitosis tends to be underestimated mainly because individuals may have difficulty in detecting their own smell or feel embarrassed to expose themselves, in line with the intimate dimension of the relationship with their mouth [22]. Subjects with a good body image pay more attention to their mouth and oral malodor [23]. Moreover, emotional state can also have a negative impact in neglect of investment in one's own body, also in terms of care and hygiene, and the subject could become more sensitive to bad smell, highlighting a multifactorial psychophysiological problem [24]. In this regard, individuals with psychiatric illnesses, including those with schizophrenia, schizoaffective disorder, depression, and bipolar disorder, may have impaired oral health [25]. For example, the presence of depressive disorder may adversely affect the patient's hygiene activities and personal care. Depression is a frequent and debilitating disorder characterized by loss of energy, anhedonia, reduced libido and feelings of sadness and despair that interfere with the daily activities of individuals. Such problems will lead to a reduction in the patient's self-esteem, leading to negative effects on the treatment of mental illness [26]. Moreover, each patient has a specific and different image of "breath smell": some subjects experience halitosis but the bad smell is neither offensive nor evident, and many authors, to highlight this condition, speak of "halitosis paradox"; i.e., while many develop wrong perceptions about their bad breath, others are not aware [23]. People who have a bad oral odor problem tend not to be aware of their bad breath, while those who do not have a bad breath problem worry excessively about having a bad odor problem. Young and middle-aged people 
tend to be more alert and anxious about their health, obtaining significantly higher scores in the OLT (organoleptic test, the gold standard to detect bad oral smell) and showing significant symptoms of anxiety and depression, with the anxiety itself increasing oral levels of volatile sulfur compounds (VSCs) [20-27]. A gender difference in the perception of halitosis was highlighted in one study [23]: $21.7 \%$ were male and $35.3 \%$ were female. Ashwath et al. [23] stated that self-perceived halitosis was more present in dental students. In addition, other significant relationships are found between self-perceived halitosis and other variables, including paternal and maternal education (illiteracy scores high compared to fathers and mothers with a diploma or university degree), dental brushing (the highest scores were related to an absence of brushing, compared to those who practiced oral hygiene three times a day) and the use of dental floss and mouthwash. Recent studies have suggested that socioeconomic inequality may affect halitosis awareness [28] and that halitosis reporters tend to have difficulty contacting the dentist [29]. A further factor to consider is the relationship between smoking and halitosis awareness: $2 \%$ of females and $14 \%$ of males report smoking, and this has been found to be significantly associated with self-perception. Gender differences in tobacco use have been attributed to cultural issues [30]. Recent studies confirm that self-perception of halitosis may be related to a psychogenic or psychosomatic disorder and has a strong psychological impact $[31,32]$.

\section{Materials and Methods}

A review strategy has been conducted to summarize the available results of experimental studies. This review was conducted according to Preferred Reporting Items for Systematic Reviews and Meta-Analyses (PRISMA) [33] (Figure 1).
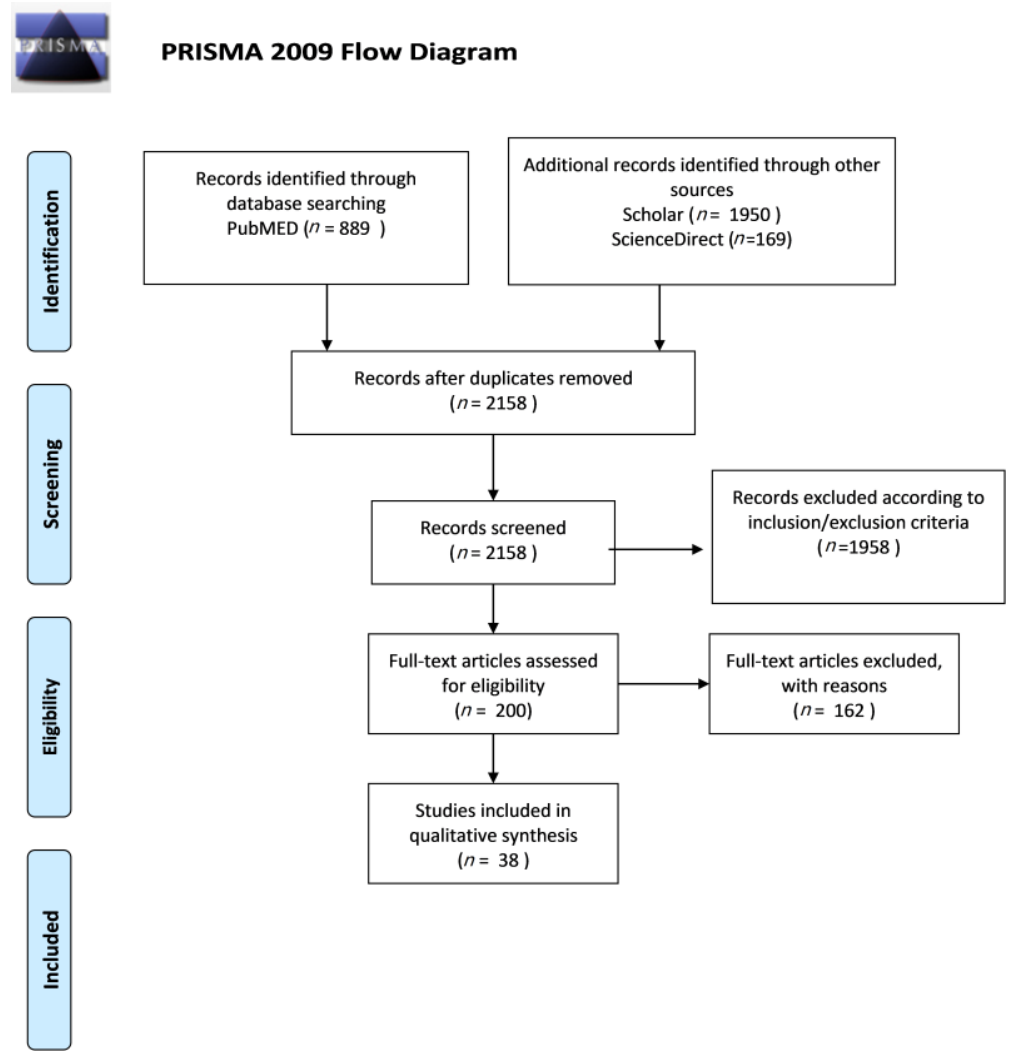

Figure 1. Prisma Flow Diagram.

\subsection{Criteria for Eligibility and Research Strategy}

To identify the studies, we performed a systematic literature search on the PubMed, Scholar and ScienceDirect databases. The search was limited to studies written in English. We identified the literature from January 2010 to January 2020 using four key terms related 
to self-perceived halitosis, namely halitosis, self-perception halitosis, psychological factors and breath odor, and two terms related to sociorelational consequences ("Halitosis and Social Relationship" OR "Social Issue of Halitosis"). The articles of 1994 and 2001 were only cited to introduce the body image theory and to link it to the perception that each individual has of his or her own smell. The electronic research strategy used is described in Table 1.

Table 1. List of search terms entered into the PubMed, Scholar and ScienceDirect search.

\begin{tabular}{cc}
\hline Number & Search Term \\
\hline 1 & Halitosis (all fields) \\
\hline 2 & Halitosis self-perception (all fields) \\
\hline 3 & Psychological factors \\
\hline 4 & Halitosis and Social Relationship \\
\hline 5 & OR \\
\hline 6 & Social Issue of Halitosis \\
\hline 7 & English (language) \\
\hline 8 & $2010 / 01 / 01$ to $2020 / 01 / 31$ (publication date)
\end{tabular}

Articles were selected online in relation to the title and abstracts; articles were read in full when titles and abstracts were consistent with the objective of our study. Following this procedure, we found 889 articles on the PubMed database, 1950 articles on Scholar and 169 articles on ScienceDirect; after applying the inclusion and exclusion criteria, the total number of relevant publications was reduced to 38 .

\subsection{Study Selection}

The articles were included in the review according to the following inclusion criteria: English language, publication in peer-reviewed scientific journals and quantitative information about self-perceived halitosis and oral hygiene. Articles were excluded based on title and abstract screen; review articles, editorial comments and case reports were also excluded. The quality of included studies was appraised by separate methods for qualitative and quantitative studies; features of study design, methodology and analysis were assessed. Qualitative studies were appraised using Critical Appraisal Skills Programme tool (CASP), while the Effective Public Health Practice Project (EPHPP) tool was used for quantitative studies. The search in the PubMed, Scholar and ScienceDirect databases provided a total of 3008 articles; no further studies meeting the inclusion criteria were identified. After eliminating duplicates, further studies were excluded according to the inclusion and exclusion criteria. After screening, 38 studies were selected as appropriate for the present review.

\subsection{Bias Risk among Studies}

In all studies included in this review, a potential bias of the database should be considered. Only articles in English have been used, which could have compromised access to articles published in other languages.

\section{Results}

According to the literature examined, halitosis is a condition that is rarely selfperceived. In particular, 10 articles focus on the self-perception of halitosis, 10 deal with halitosis by defining it and analyzing the epidemiology, 1 study focuses on body image related to the perception of one's smell, 7 studies analyze the different psychological factors related to halitosis and 10 studies address the sociorelational problems caused by halitosis. 
Quality assessment of the selected works was performed using CASP and EPHPP tools; the results of quality assessment are reported in Tables 2 and 3. Most of the qualitative studies were found to have good quality, while some of the quantitative works showed relevant methodological weaknesses such as selection bias, unsatisfactory design and presence of confounders. Despite these limitations, studies made it possible to understand the importance of this condition and the influence it exerts on the psychorelational status of affected subjects. A summary of the selected studies is reported in Table 4. Additionally, references to the selected articles were examined in order to identify further studies that could meet inclusion criteria (Table 5). Studies found that the prevalence of self-perceived halitosis was $22.8 \%$ among the participants. The majority of subjects with self-perceived halitosis experienced bad breath on awakening $(83.5 \%)$. Self-perceived halitosis was more prevalent among males than females, whereas no statistically significant differences were found between age groups. A statistically significant relationship was found between self-perceived halitosis and mouth cleaning time, and a statistically significant relationship was found between self-perceived halitosis and mouth cleaning time, shisha use or cigarette smoking [16]. In this study, it was found that the more people perceived their oral odor, the more likely they were to maintain a distance. A subgroup of individuals was identified who reported maintaining a certain distance when meeting other people, despite a self-perceived "fresh" oral odor. Self-perceived halitosis leads people to keep their distance in social interactions. The ability to recognize and perceive one's oral condition can be influenced by socioeconomic variables such as age, gender and level of education [31]. There are frequent cases of oral and dental problems in patients with depression, anxiety or schizophrenia [26]. It has been possible to understand how people have difficulty recognizing the presence of halitosis and have limited knowledge about this condition [11]. It is clear that halitosis is an unpleasant symptom and can create relational difficulties with consequences for the individual's quality of life [3]. The participants in the study were healthy subjects. Participants in some studies underwent organoleptic tests to measure breathing odor and specific questionnaires were given. Some patients with halitosis were compared with healthy subjects.

This study has identified the importance of the consequences that the perception of bad breath has on the psychorelational side and, in general, on patients' quality of life. 
Table 2. Critical Appraisal Skills Programme (CASP)

\begin{tabular}{|c|c|c|c|c|c|c|c|c|c|}
\hline & $\begin{array}{l}\text { Dico, G.L. } \\
\text { (2018) [20] }\end{array}$ & $\begin{array}{l}\text { Eli, I., et al. } \\
(2001)[22]\end{array}$ & $\begin{array}{l}\text { Heboyan, A., } \\
\text { et al. (2019) [17] }\end{array}$ & $\begin{array}{l}\text { Kapoor, U., } \\
\text { et al. (2016) [12] }\end{array}$ & $\begin{array}{l}\text { Kisely, S. } \\
\text { (2016) [25] }\end{array}$ & $\begin{array}{l}\text { Madhushankari, } \\
\text { G.S., et al. } \\
\text { (2015) [8] }\end{array}$ & $\begin{array}{l}\text { Ozen, M.E., } \\
\text { et al. (2015) [13] }\end{array}$ & $\begin{array}{l}\text { Slade, P.D. } \\
\text { (1994) [21] }\end{array}$ & $\begin{array}{l}\text { Torales, J., et al. } \\
\quad \text { (2017) [26] }\end{array}$ \\
\hline $\begin{array}{l}\text { Item } 1 . \text { Was there a clear } \\
\text { statement of the aim of } \\
\text { the research? }\end{array}$ & Y & Y & $\mathrm{Y}$ & $\mathrm{Y}$ & $\mathrm{Y}$ & $\mathrm{Y}$ & Y & Y & Y \\
\hline $\begin{array}{l}\text { Item } 2 . \text { Is a qualitative } \\
\text { methodology appropriate? }\end{array}$ & Y & $\mathrm{Y}$ & Y & Y & $\mathrm{Y}$ & Y & Y & $\mathrm{Y}$ & Y \\
\hline $\begin{array}{l}\text { Item } 4 . \text { Was the recruitment } \\
\text { strategy appropriate to the } \\
\text { aims of the research? }\end{array}$ & Y & Y & $\mathrm{U}$ & Y & $\mathrm{Y}$ & Y & $\mathrm{U}$ & Y & Y \\
\hline $\begin{array}{c}\text { Item } 5 . \text { Was the data collected } \\
\text { in a way that addressed the } \\
\text { research issue? }\end{array}$ & Y & $\mathrm{Y}$ & $\mathrm{U}$ & Y & $\mathrm{Y}$ & $\mathrm{Y}$ & Y & Y & $\mathrm{Y}$ \\
\hline $\begin{array}{c}\text { Item } 7 . \text { Have ethical issues } \\
\text { been taken into consideration? }\end{array}$ & $\mathrm{U}$ & $\mathrm{Y}$ & $\mathrm{Y}$ & $\mathrm{U}$ & $\mathrm{N}$ & $\mathrm{N}$ & $\mathrm{N}$ & $\mathrm{N}$ & $\mathrm{N}$ \\
\hline $\begin{array}{c}\text { Item } 8 . \text { Was the data analysis } \\
\text { sufficiently rigorous? }\end{array}$ & Y & Y & $\mathrm{U}$ & Y & Y & Y & Y & Y & Y \\
\hline $\begin{array}{l}\text { Item 9. Is there a clear } \\
\text { statement of finding? }\end{array}$ & $\mathrm{Y}$ & $\mathrm{Y}$ & $\mathrm{Y}$ & Y & $\mathrm{Y}$ & Y & Y & $\mathrm{Y}$ & $\mathrm{Y}$ \\
\hline $\begin{array}{c}\text { Item } 10 . \text { How valuable is } \\
\text { the research? }\end{array}$ & Y & Y & Y & $\mathrm{Y}$ & Y & $\mathrm{Y}$ & Y & Y & Y \\
\hline Overall Score & 9 & 9.5 & 8 & 9.5 & 8 & 8.5 & 7.5 & 8 & 8.5 \\
\hline
\end{tabular}

Y: Yes (1); N: No (0); U: Unclear (0.5). 
Table 3. Effective Public Health Practice Project (EPHPP).

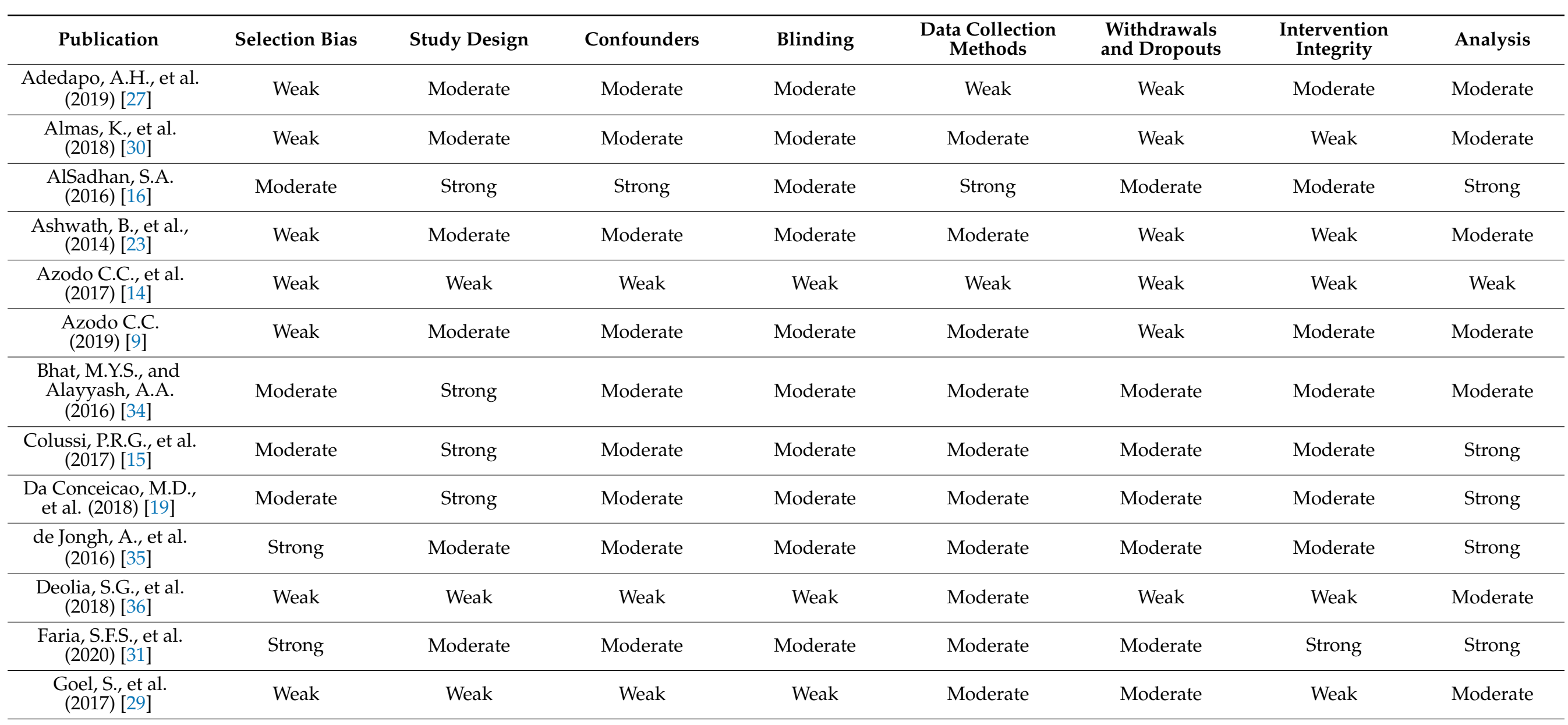


Table 3. Cont.

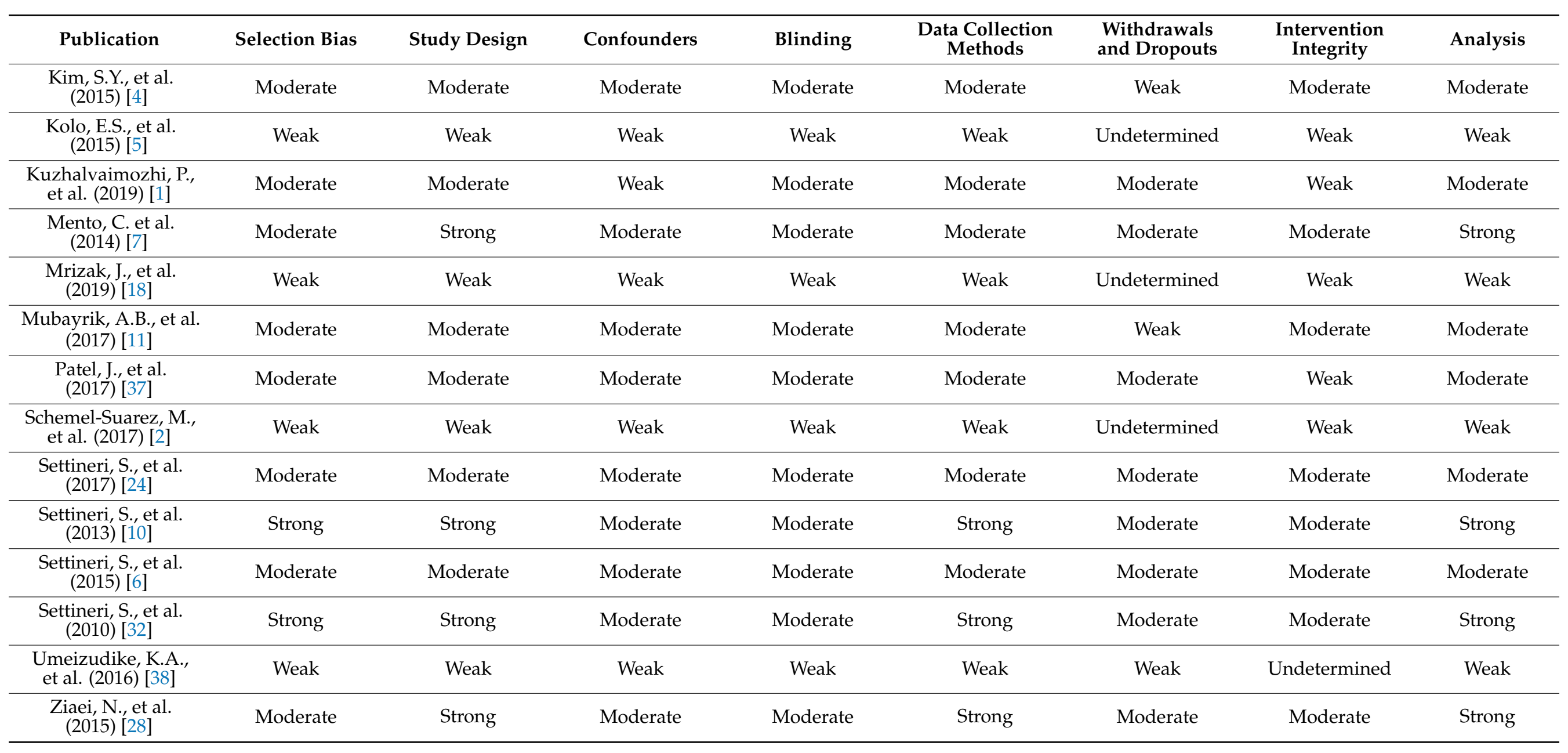


Table 4. Characteristics of the studies.

\begin{tabular}{|c|c|c|c|c|c|}
\hline Publication & Aims & Sample Size and Characteristics & Group Characteristics & Mesaurement Type & Results \\
\hline $\begin{array}{l}\text { Adedapo, A.H., et al. } \\
\text { (2019) }\end{array}$ & $\begin{array}{l}\text { This study determines the } \\
\text { presence of five putative } \\
\text { periodontal pathogens, namely } \\
\text { Actinobacillus } \\
\text { actinomycetemcomitans, } \\
\text { Fusobacterium nucleatum, } \\
\text { Porphyromonas gingivalis, } \\
\text { Prevotella intermedia and } \\
\text { Treponema denticola, on the } \\
\text { tongue dorsa of halitosis and } \\
\text { nonhalitosis patients using a 16S } \\
\text { rDNA-directed polymerase chain } \\
\text { reaction assay. }\end{array}$ & $\begin{array}{l}84 \text { patients presenting } \\
\text { self-complaints of halitosis at the } \\
\text { Oral Diagnosis Clinic, University } \\
\text { College Hospital, Ibadan, } \\
\text { between January } 2008 \text { and } \\
\text { October } 2010\end{array}$ & $\begin{array}{l}\text { The cases consisted of } 24 \text { males } \\
\text { with mean age of } 37.7 \pm 10.7 \\
\text { years and } 13 \text { females with mean } \\
\text { age of } 40.8 \pm 14.9 \text { years. The } \\
\text { controls consisted of } 15 \text { males } \\
\text { with mean age of } 34.9 \pm 12.7 \\
\text { years and } 22 \text { females with mean } \\
\text { age of } 35.4 \pm 14.2 \text { years. }\end{array}$ & $\begin{array}{c}\text { VSC measurements were made with } \\
\text { a portable industrial sulfide monitor } \\
\text { (Interscan Corp., Chatsworth, CA), } \\
\text { zeroed on ambient air before each } \\
\text { measurement. }\end{array}$ & $\begin{array}{l}\text { Halitosis is affected by gender, with } \\
\text { males having it more than females. Males } \\
\text { also tend to present more with } \\
\text { self-reported complaints of halitosis than } \\
\text { females. Age does not appear to } \\
\text { contribute to the incidence of halitosis. }\end{array}$ \\
\hline $\begin{array}{l}\text { Almas, K., et al. } \\
\text { (2018) }\end{array}$ & $\begin{array}{l}\text { Objective of the study was to } \\
\text { evaluate self-perceived oral } \\
\text { malodor (OM) and to correlate } \\
\text { this with oral hygiene practices. }\end{array}$ & $\begin{array}{l}372 \text { Saudi dental students: } 109 \\
\text { students were males and } 116 \\
\text { were females. The mean age of } \\
\text { the subjects was 19-25. }\end{array}$ & $\begin{array}{l}\text { Saudi dental students in the } \\
\text { College of Dentistry at the Imam } \\
\text { Abdulrahman Bin Faisal } \\
\text { University (IAU), in the Eastern } \\
\text { Province of Saudi Arabia. }\end{array}$ & $\begin{array}{l}\text { The questionnaire contained three } \\
\text { parts, comprising sociodemographic } \\
\text { factors, subject's perceptions of OM, } \\
\text { and the social effects thereof. }\end{array}$ & $\begin{array}{l}\text { The results state that there is a prevalence } \\
\text { of malodor among dental students. In } \\
\text { addition, regular flossing and removal of } \\
\text { tongue coating can significantly reduce } \\
\text { malodor. }\end{array}$ \\
\hline $\begin{array}{l}\text { AlSadhan, S.A. } \\
\text { (2016) }\end{array}$ & $\begin{array}{l}\text { This cross-sectional observational } \\
\text { study was conducted to } \\
\text { determine the prevalence of } \\
\text { self-perceived halitosis among } \\
\text { adults in Riyadh, Saudi Arabia, } \\
\text { and to assess the relation of } \\
\text { halitosis with certain } \\
\text { sociodemographic factors, oral } \\
\text { habits and health practices. }\end{array}$ & $\begin{array}{l}3000 \text { participants, both males and } \\
\text { females, including senior high } \\
\text { school students, college students } \\
\text { and employees working in } \\
\text { governmental offices. }\end{array}$ & $\begin{array}{l}\text { The college students were } \\
\text { selected from the major } \\
\text { universities in Riyadh. There } \\
\text { were } 15 \text { locations for males and } \\
15 \text { for females ( } 5 \text { schools, } 5 \\
\text { universities and } 5 \text { governmental } \\
\text { offices for each gender). }\end{array}$ & $\begin{array}{l}\text { The questionnaire was made up of } 3 \\
\text { parts: the first part was related to } \\
\text { certain sociodemographic factors } \\
\text { including gender, age, educational } \\
\text { level and employment; the second } \\
\text { part was related to the participant's } \\
\text { perception of any malodor (halitosis) } \\
\text { and its history and social effects; and } \\
\text { the third part concerned certain oral } \\
\text { hygiene and health habits. }\end{array}$ & $\begin{array}{l}\text { The prevalence of self-perceived halitosis } \\
\text { was } 22.8 \% \text { among the participants. The } \\
\text { majority of subjects with self-perceived } \\
\text { halitosis experienced bad breath on } \\
\text { awakening ( } 83.5 \% \text { ). Self-perceived } \\
\text { halitosis was more prevalent among } \\
\text { males than females, whereas no } \\
\text { statistically significant differences were } \\
\text { found between age groups. A statistically } \\
\text { significant relationship was found } \\
\text { between self-perceived halitosis and } \\
\text { mouth cleaning time, and a significant } \\
\text { relationship was found between } \\
\text { self-perceived halitosis and mouth } \\
\text { cleaning time, shisha use or cigarette } \\
\text { smoking. }\end{array}$ \\
\hline
\end{tabular}


Table 4. Cont.

\section{Publication} Aims
Sample Size and Characteristics

The aim of this study was to Ashwath, B., et al. evaluate self-perception of ora

malodor and oral hygiene hab
285 participants in the age range of 18 to 22 .
Undergraduate students of Madha Dental College and Hospital Chennai.

\section{Group Characteristics}

Mesaurement Type

\section{Results}

The questionnaire used included ten questions that assessed the presence and self-perception of halitosis and treatment (self or professional) for halitosis. It also evaluated the subjects' oral hygiene habits, including the frequency of toothbrushing, the use of interdental aids and mouth rinsing.

Demographic characteristics,

erception of value of fresh breath in social contact, rank of halitosis in firs impression impairment, frequency of

Azodo, C.C., et al. The objective of this study was to (2017) assess the relational impact of halitosis.
Undergraduates of University of Benin, Nigeria.

encounter with halitosis sufferers and their interactional difficulties and readiness to inform sufferers about the condition were assessed usin self-administered validated questionnaire

A questionnaire assessing health

status, quality of life, intelligence caring, trustworthiness,

The objective of this study was to attractiveness, sexiness, determine the social trait rating of halitosis sufferers by others who are Nigerian

A total of 245 individuals aged between 17 and 35 , comprising 100 males and 145 females.

Main (Ugbowo) campus residential undergraduates of University of Benin, Nigeria.

aggressiveness, happiness, pleasantry, motivation, spirituality, satisfaction with life and social life activity of halitosis sufferers was used to collect data.

The goal was to try to evaluate

Bhat, M.Y.S., and

the social stigma related to

Alayyash, A.A halitosis and compare it between (2016)
308 were from the Kingdom of Saudi Arabia (Jeddah and Abha) and 304 were from the United Kingdom (Cardiff, Edinburgh and Glasgow).
Questionnaire of 10 articles related to self-awareness on the state of personal halitosis and on the importance of the social importan
The results of this study indicate a higher prevalence of halitosis among this population of dental students. The difference in reporting self-perception of halitosis between females and males was found to be statistically significant $(p<0.05)$. Significant difference was found for use of mouth wash, presence of carious teeth bleeding gums and use of tongue cleaners between females and males.

Halitosis was considered to be the second most important factor in social interaction after body odor. The majority of

respondents believed that those suffering from halitosis had difficulty finding a good job or getting married or suffered from marital disharmony.

In this study, halitosis sufferers' low ratings of pleasantness, motivation, life satisfaction and happiness made them less attractive and sexy, and this had an influence on social relationships

Saudi and selected UK populations have experienced social embarrassment because of halitosis. A significant amount of stigma associated with halitosis persists in both countries. 
Table 4. Cont.
Publication
Aims

\section{Sample Size and Characteristics}

This study aimed to assess the impact of oral health on the quality of life of adolescents. schools and 7 private schools.
(2017)
736 adolescents from 16 public

The students from public and private schools from Passo

pundo, Brazil. All students were aged between 15 and 19. Included 411 with a halitosis 18-74) and 25 without a

try to determine the validity of the inventory of the

Da Conceicao, M.D., consequences of halitosis (ICH) et al. (2018) and to study the relationship between these consequences and SAD.

The aim was to determine the de Jongh, A., et al. impact of self-perceived halitosis (2016) on social interactions and the effect of using an oral rinse to manage halitosis.

436 individuals.

plaint (84\% women; age 18-55). Among the 411 individuals complaining of halitosis, 164 were selected from a halitosis clinic.

A participants were members of an online survey members of an online survey panel assembled by the Internet

For study A, 1083 subjects. For study B, 292 people.

For study B, the potential For study B, the potential
participants were personally participants were personally
approached in a square in the entertainment area of the city of Haarlem in the Netherlands.

This study aimed to understand the psychological and social

Deolia, S.G., et al. effects of halitosis among youn (2018) adults and to correlate their psychosocial effects with different levels of halitosis.
Young adults between the ages of 18 and 25 visiting a private dental 200 patients (male and female) college in Maharashtra who perceived themselves as sufferers of halitosis.

\section{Mesaurement Type}

The questionnaire including demographic data, socioeconomic condition, general health behavior health record and oral health health record and oral health self-perception was applied with
group of questions from the group of questions from the PCATool-SB Brazil adult version. Instrument OHIP-14 was used to assess quality of life.

Seven instruments were used for this study: a sociodemographic questionnaire, Halitosis Consequences Inventory (ICH) Social Phobia Inventory and its shortened version, the Liebowitz Social Anxiety Scale, Social Fear of Negative Evaluation scale.

The questionnaire contained questions about oral perception The questionnaire included to the psychological and social impact of oral malodor on their daily lives.

\section{Results}

Adolescents deprived of their liberty experience a strong impact on oral health quality (OHRQoL). The number of decayed teeth and exposure to smoking were associated with a greater impact on associated with a lower impact on OHRQoL.

The ICH is an important tool for determining the consequences of bad breath, allowing identification of people who may require screening for social anxiety disorder (SAD).

In this study, it was found that the more people perceived their oral odor, the more likely they were to maintain a distance. A subgroup of individuals was identified who reported maintaining a certain distance when meeting other people, despite a self-perceived "fresh" oral odor.

The younger age group showed a higher incidence of halitosis than the older age group. Both genders did not show much difference with respect to the

psychological impact of halitosis; were present more in women. 
Table 4. Cont.

\begin{tabular}{|c|c|c|c|c|c|}
\hline Publication & Aims & Sample Size and Characteristics & Group Characteristics & Mesaurement Type & Results \\
\hline Dico, G L. (2018) & $\begin{array}{l}\text { The goal of this article was to } \\
\text { discuss self-perception theory } \\
\text { and its influence on recent } \\
\text { research; it was argued that } \\
\text { introspection is not an } \\
\text { autonomous research method for } \\
\text { discussing the epistemological } \\
\text { implications of this behavioral } \\
\text { attitude on psychology. }\end{array}$ & & & & $\begin{array}{l}\text { This study discussed introspection as an } \\
\text { autonomous research method and } \\
\text { independent source of data for } \\
\text { psychology. }\end{array}$ \\
\hline $\begin{array}{l}\text { Faria, S.F.S., et al. } \\
\qquad(2020)\end{array}$ & $\begin{array}{l}\text { The aim of the study was to } \\
\text { evaluate the prevalence of } \\
\text { self-reported halitosis and its } \\
\text { predictors and to determine the } \\
\text { accuracy of estimates of the } \\
\text { self-reported measures with the } \\
\text { clinical assessment of halitosis. }\end{array}$ & 5420 individuals. & $\begin{array}{l}\text { Teaching staff, administrative } \\
\text { personnel and ongoing students } \\
\text { from Federal University of Minas } \\
\text { Gerais. }\end{array}$ & $\begin{array}{c}\text { Questionnaire containing } \\
\text { sociodemographic, medical and } \\
\text { dental data and self-reported halitosis } \\
\text { measures; organoleptic test (OLT). }\end{array}$ & $\begin{array}{l}\text { Self-reported halitosis was mainly } \\
\text { associated with socioeconomic variables } \\
\text { (age, gender, education level), oral health } \\
\text { parameters (gingival bleeding, gingival } \\
\text { infection, tongue coating, general oral } \\
\text { health assessment) and impacts on daily } \\
\text { activities (family/social environment and } \\
\text { intimate relationships). Prevalence rates } \\
\text { of self-reported halitosis can be } \\
\text { considered moderate. }\end{array}$ \\
\hline Goel, S., et al. (2017) & $\begin{array}{l}\text { The aim of this study was to } \\
\text { assess the level of knowledge and } \\
\text { attitude of the Indian population } \\
\text { toward self-perceived halitosis, } \\
\text { about its possible causes, } \\
\text { available treatments, its influence } \\
\text { on social relations and level of } \\
\text { confidence. }\end{array}$ & $\begin{array}{l}200 \text { subjects participated in the } \\
\text { study. }\end{array}$ & $\begin{array}{l}\text { The outpatient department of a } \\
\text { dental hospital. }\end{array}$ & $\begin{array}{l}\text { Questionnaire that investigates } \\
\text { sociodemographic data, presence or } \\
\text { absence of medical conditions and } \\
\text { habits, knowledge of the causes and } \\
\text { treatment of bad smells and oral } \\
\text { hygiene practices. }\end{array}$ & $\begin{array}{l}\text { This exploratory study shows that Indian } \\
\text { adolescents } \\
\text { are aware of the problem, but there is no } \\
\text { clear knowledge necessary to have an } \\
\text { understanding and to adopt a healthy } \\
\text { lifestyle. }\end{array}$ \\
\hline
\end{tabular}


Table 4. Cont.

Publication Aims

The objective of the study was to analyze the causative factors, diagnostic methods and

Heboyan, A., et al.
(2019) $\quad \begin{gathered}\text { treatment options aimed at } \\ \text { maintaining oral health as well as }\end{gathered}$ restoring an individual's mental health, self-confidence and social status.

\section{Sample Size and Characteristics}

Mesaurement Type

\section{Results}

Early diagnosis of halitosis is only the identification of the

causal factors makes possible an adequate

customized treatment. Bad oral odor can often be influenced by general somatic diseases and the intake of various medications. Thus, treatment should be aimed at maintaining proper oral

$$
\text { hygiene. }
$$

Halitosis is an extremely unpleasant feature of sociocultural interactions and can have long-term negative side effects on psychosocial relationships. An interdisciplinary approach to the

the development of a systematic

Kapoor, U., et al. flow of events to arrive at the

(2016) best management of the halitosis

from the primary care

practitioner's point of view.

treatment of halitosis should be used in order to prevent misdiagnosis or unnecessary treatment.

In this study, factors highlighted as

A test was used to collect information lating to gender; age; residence;

This study was conducted to

Kim, S.Y., et al. estimate the prevalence and (2015) associated factors of subjective halitosis in adolescents
359,263 participants $(184,801$ males and 174,462 females) ranging in age from 12 to 18 .
Young people from Korea. subjective health; stress level;

economic level; alcohol consumption

moking: and frequency of intake of

fruit, fizzy drinks, fast food, instant pasta, sweet foods and vegetables. related to halitosis were poor health

lower economic levels. The prevalence

subjective halitosis in the adolescents studied was $23.6 \%$. Specific psychosocial factors and dietary intake were related to halitosis.

This article discusses the

Th-way association between

oral and mental health. On the

one hand, the prospect of dental

treatment can lead to anxiety an phobia.

Kisely, S. (2016)

On the other, many psychiatric

disorders, such as severe mental

illness, affective disorders anc

illness, affective disorders and

with dental disease.

Dental diseases can lead to teeth loss, and people with severe mental illness have 2.7 times the likelihood of losing all their teeth compared with the genera population. 
Table 4. Cont.

\section{Publication} Aims

This study aimed to describe the psychological and social

Kolo, E.S., et al.

(2015)

problems of adult patients with halitosis.
36 people, 20 females and 16 males aged between 18 and 62
Adult patients from the Aminu

Kano educational hospital (northern Nigeria).

\section{Group Characteristics}

u

Mesaurement Type
A self-administered questionnaire
was explained and administered to

was explained and administered to the patients at their first visit to the clinic by the authors. The content of the questionnaire included personal bio-data and questions related to oral malodor. Subsequently, the patients were asked to assess the severity of their bad breath using the visual analog scale (VAS).

\begin{tabular}{|c|c|c|c|c|c|}
\hline $\begin{array}{l}\text { Kuzhalvaimozhi, P., } \\
\quad \text { et al. (2019) }\end{array}$ & $\begin{array}{l}\text { Objective of the study was to } \\
\text { assess self-perception, } \\
\text { knowledge and attitude of } \\
\text { halitosis among patients } \\
\text { attending a dental hospital in } \\
\text { Chennai. }\end{array}$ & 300 patients. & $\begin{array}{l}\text { Patients who visited a dental } \\
\text { hospital in South India. }\end{array}$ & $\begin{array}{l}\text { A self-structured questionnaire was } \\
\text { implemented. }\end{array}$ & $\begin{array}{l}\text { Most of the participants did not have } \\
\text { self-perceived halitosis and most } \\
\text { participants brushed their teeth twice a } \\
\text { day, used mouthwash regularly and had } \\
\text { knowledge of halitosis. }\end{array}$ \\
\hline $\begin{array}{l}\text { Madhushankari, } \\
\text { G.S., et al. (2015) }\end{array}$ & $\begin{array}{l}\text { This review covers the } \\
\text { pathophysiology and various } \\
\text { etiologies of halitosis, the } \\
\text { knowledge of which helps } \\
\text { improve treatment options. }\end{array}$ & & & & $\begin{array}{l}\text { The patients with halitosis initially turn to } \\
\text { dentists for improvement of the condition. } \\
\text { Research into volatile sulfur compounds } \\
\text { (VSCs) and their effect on oral tissues has } \\
\text { made the problem of halitosis a cause for } \\
\text { real concern. }\end{array}$ \\
\hline $\begin{array}{l}\text { Mento, C., et al. } \\
\quad(2014)\end{array}$ & $\begin{array}{l}\text { The aim was to determine to } \\
\text { what extent dental anxiety can be } \\
\text { explained by looking at patients' } \\
\text { characteristics solely or by } \\
\text { considering also latent } \\
\text { aggressiveness that could be } \\
\text { manifested before and during the } \\
\text { dental treatment. }\end{array}$ & $\begin{array}{l}\text { A random sample of patients } \\
\text { undergoing dental treatment at } \\
\text { several settings located in two } \\
\text { regions in Southern Italy. }\end{array}$ & $\begin{array}{l}\text { Group 1: } 153 \text { individuals (15-26 } \\
\text { years); Group 2: } 190 \text { individuals } \\
\text { (27-42 years); Group 3: } 170 \\
\text { individuals ( } 43-70 \text { years). }\end{array}$ & $\begin{array}{l}\text { Dental Anxiety Scale (DAS), The } \\
\text { Aggression Questionnaire (AQ), and } \\
\text { Patient Health Questionnaire (PHQ). }\end{array}$ & $\begin{array}{l}\text { The results of the sample estimates show } \\
\text { the importance of aggressiveness in the } \\
\text { development of dental anxiety; a } \\
\text { significant influence is also exerted by the } \\
\text { presence of depressive symptoms. } \\
\text { Furthermore, there are no significant } \\
\text { gender differences, and there is a } \\
\text { nonlinear relationship with age; the most } \\
\text { significant age group is between } 27 \text { and } \\
42 \text { years old. }\end{array}$ \\
\hline
\end{tabular}

This study revealed that most of the adult patients had halitophobia, and most of them had no associated psychosocial problems. Furthermore, their bad breath was not influenced by gender or the duration of illness. 
Table 4. Cont.

\begin{tabular}{|c|c|c|c|c|c|}
\hline Publication & Aims & Sample Size and Characteristics & Group Characteristics & Mesaurement Type & Results \\
\hline $\begin{array}{c}\text { Mrizak, J., et al. } \\
\text { (2019). }\end{array}$ & $\begin{array}{l}\text { Halitophobia is a condition } \\
\text { characterized by an excessive } \\
\text { preoccupation with the belief of } \\
\text { having halitosis. Cognitive } \\
\text { behavioral therapy (CBT) was } \\
\text { successfully used to treat a man } \\
\text { in his 20s who presented } \\
\text { important anxiety, avoidance and } \\
\text { safety behaviors; isolation; and } \\
\text { depressed mood. }\end{array}$ & A 20-year-old man. & $\begin{array}{l}\text { A man presenting important } \\
\text { anxiety, avoidance and safety } \\
\text { behaviors; isolation; and } \\
\text { depressed mood. }\end{array}$ & $\begin{array}{c}\text { Hamilton Anxiety Rating Scale } \\
\text { (HAM-A) and Hamilton Depression } \\
\text { Rating Scale (HAM-D). }\end{array}$ & $\begin{array}{l}\text { This study suggests that CBT techniques, } \\
\text { most commonly used in anxiety disorders } \\
\text { and obsessive-compulsive disorder, can } \\
\text { be adapted to halitophobia. }\end{array}$ \\
\hline $\begin{array}{l}\text { Mubayrik, A.B., et al. } \\
\text { (2017) }\end{array}$ & $\begin{array}{l}\text { This study was designed to } \\
\text { measure self-perception, } \\
\text { knowledge, and awareness of } \\
\text { halitosis among female university } \\
\text { students in Saudi Arabia. }\end{array}$ & 440 young women. & $\begin{array}{c}\text { Students from various majors in } \\
\text { classrooms and gathering areas } \\
\text { of King Saud University's female } \\
\text { campus. }\end{array}$ & $\begin{array}{l}\text { The questionnaire consisted of the } \\
\text { following: } \\
\text { 1) a cover page with a request for } \\
\text { cooperation and instructions; } \\
\text { 2) demographic questions; } \\
\text { 3) substantive questions exploring } \\
\text { the respondents' self-perception and } \\
\text { awareness of halitosis along with } \\
\text { their knowledge about causes and } \\
\text { management of oral malodor. }\end{array}$ & $\begin{array}{l}\text { The survey revealed low self-perception } \\
\text { and limited knowledge about halitosis. } \\
\text { Self-perception of halitosis was low, while } \\
\text { a higher percentage indicated that they } \\
\text { noticed people with halitosis. Most } \\
\text { participants thought that the } \\
\text { gastrointestinal tract was the primary } \\
\text { source of halitosis. }\end{array}$ \\
\hline Patel, J., et al. (2017) & $\begin{array}{l}\text { The aim was to evaluate the } \\
\text { association of social anxiety with } \\
\text { oral hygiene status and tongue } \\
\text { coating among patients with } \\
\text { subjective halitosis. }\end{array}$ & 321 subjects. & $\begin{array}{c}\text { Subjects aged } 18 \text { or older } \\
\text { presenting in the outpatient } \\
\text { department with the complaint } \\
\text { of halitosis. }\end{array}$ & $\begin{array}{l}\text { Social anxiety was assessed with the } \\
\text { 24-item self-report version of the } \\
\text { Liebowitz Social Anxiety Scale } \\
\text { (LSAS-SR). }\end{array}$ & $\begin{array}{c}\text { This study revealed that social anxiety, } \\
\text { poor oral hygiene and tongue coating } \\
\text { were associated with subjective halitosis. } \\
\text { Comparison of oral clinical parameters } \\
\text { between the sexes revealed that poor oral } \\
\text { hygiene was observed among male } \\
\text { participants. }\end{array}$ \\
\hline
\end{tabular}


Table 4. Cont.

\begin{tabular}{|c|c|c|c|c|c|}
\hline Publication & Aims & Sample Size and Characteristics & Group Characteristics & Mesaurement Type & Results \\
\hline $\begin{array}{l}\text { Schemel-Suárez, M., } \\
\text { et al. (2017) }\end{array}$ & $\begin{array}{l}\text { The objective of this study was to } \\
\text { estimate the prevalence of } \\
\text { halitosis (with subjective and } \\
\text { objective methods), evaluate the } \\
\text { immediate effect of chewing gum } \\
\text { on volatile sulfur compounds } \\
\text { (VSCs), assess the perception of } \\
\text { halitosis by dentistry students } \\
\text { and estimate the distribution of } \\
\text { positive and negative frequencies, } \\
\text { when comparing objective and } \\
\text { subjective methods for the } \\
\text { diagnosis of halitosis. }\end{array}$ & 80 dentistry students. & $\begin{array}{l}\text { The sample comprised } 80 \\
\text { individuals: } 59 \text { women and } 21 \\
\text { men aged from } 18 \text { to } 40 .\end{array}$ & $\begin{array}{l}\text { Questionnaire, the simplified oral } \\
\text { hygiene index, the Winkel index, } \\
\text { organoleptic test and gas } \\
\text { chromatography. }\end{array}$ & $\begin{array}{l}\text { The prevalence of halitosis in the studied } \\
\text { sample was high, considering that it } \\
\text { comprised healthy individuals. }\end{array}$ \\
\hline $\begin{array}{l}\text { Settineri, S., et al. } \\
\qquad(2017)\end{array}$ & $\begin{array}{l}\text { The study aimed to investigate } \\
\text { the psychological impact of oral } \\
\text { disorders on people's emotional } \\
\text { well-being, with a particular } \\
\text { attention to gender and age } \\
\text { differences. }\end{array}$ & $\begin{array}{l}\text { The whole sample consisted of } \\
263 \text { dental patients, all belonging } \\
\text { to private dental surgeries of the } \\
\text { center of Messina. }\end{array}$ & $\begin{array}{c}\text { For the analysis, the authors } \\
\text { considered only the valid cases: } \\
130 \text { of them were females }(56.8 \%) \\
\text { and } 99 \text { of them were males } \\
(43.2 \%) \text {, for a total of } 229 \\
\text { participants. }\end{array}$ & $\begin{array}{l}\text { The Profile of Mood States (POMS) } \\
\text { and Oral Health Impact Profile } \\
\text { (OHIP-14). }\end{array}$ & $\begin{array}{l}\text { The results of this study showed a } \\
\text { significant relationship between the } \\
\text { perception of the patient's oral health and } \\
\text { the mood states experienced. }\end{array}$ \\
\hline $\begin{array}{l}\text { Settineri, S., et al. } \\
\text { (2013) }\end{array}$ & $\begin{array}{l}\text { The aim of the study was to } \\
\text { analyze, by means of a } \\
\text { questionnaire on disgust, any } \\
\text { gender differences regarding the } \\
\text { feeling of disgust in its various } \\
\text { dimensions, viewed both } \\
\text { individually and globally. }\end{array}$ & $\begin{array}{l}\text { A sample of } 1587 \text { subjects was } \\
\text { taken from the town of Messina } \\
\text { (676 males and } 911 \text { females). } \\
\text { Subjects were contacted by } \\
\text { medicine students of Messina } \\
\text { University Hospital. }\end{array}$ & $\begin{array}{l}\text { The age range of participants was } \\
\text { between } 10 \text { and } 90 .\end{array}$ & The synthetic disgust index (SDI) & $\begin{array}{l}\text { Disgust and oral contamination showed a } \\
\text { reduction in the SDI in the group aged } \\
18-39 \text { years and a maximum score in the } \\
\text { group of subjects aged } 40-64 \text { years. } \\
\text { Disgust and oral contamination showed a } \\
\text { reduction in the SDI in the } 18-39 \text { age } \\
\text { group with a general tendency to } \\
\text { decrease with age. }\end{array}$ \\
\hline $\begin{array}{l}\text { Settineri, S., et al. } \\
\text { (2015) }\end{array}$ & $\begin{array}{l}\text { The aim of the study was to } \\
\text { investigate the relationship } \\
\text { between psychosocial impact, } \\
\text { levels of self-esteem and the } \\
\text { possible connection with eating } \\
\text { habits of adolescents under } \\
\text { orthodontic treatment. }\end{array}$ & $\begin{array}{l}\text { The adolescents in treatment } \\
\text { from } 0 \text { to } 60 \text { months at the Clinic } \\
\text { of Orthodontics and Dentistry of } \\
\text { Messina, Messina, Italy. }\end{array}$ & $\begin{array}{c}\text { Sixty-one adolescents, aged } \\
\text { between } 12 \text { and } 22 \text { years (mean = } \\
15.6 \pm 2.8) .\end{array}$ & $\begin{array}{l}\text { Eating Attitudes Test, the Rosenberg } \\
\text { Self Esteem Scale, and the } \\
\text { Psychosocial Impact of Dental } \\
\text { Aesthetics Questionnaire. }\end{array}$ & $\begin{array}{l}\text { The data did not show a direct connection } \\
\text { between eating disorder and dental } \\
\text { aesthetics. Adolescents under orthodontic } \\
\text { treatment in the first phase of orthodontic } \\
\text { appliance use showed peculiar eating } \\
\text { habits and were more psychologically } \\
\text { affected by dental aesthetics. }\end{array}$ \\
\hline
\end{tabular}


Table 4. Cont.

Publication Aims
The aim of this study was to examine behavior in a sample of Settineri, S., et al. Italian subjects with reference to (2010)

emotional state, specifically the

presence of dental anxiety. self-reported halitosis and
Sample Size and Characteristics

1052 subjects, 623 females and 388 males, aged between 15 and 65 years old.
Subjects were recruited in the waiting room of dental clinics in Messina and Reggio Calabria.

\section{Group Characteristics}

in

Mesaurement Type
Instruments used were as follows:
self-report questionnaire to detect
self-reported halitosis and other

elf-report questionnaire to detect
variables possibly linked to it:

absence of medical and dental

pathologies, any allergies, oral

hygiene practices, medication,

smoking and alcohol consumption,

the importance attributed to one's

own mouth and that of others; Dental Anxiety Scale (DAS).
The rate of self-reported halitosis was $19.39 \%$. The factors related to halitosis were anxiety about relationships with the dental patient (relational dental anxiety), alcohol consumption, gum disease, age > 30 years, female sex, poor oral hygiene, general anxiety and urinary system$$
\text { diseases. }
$$

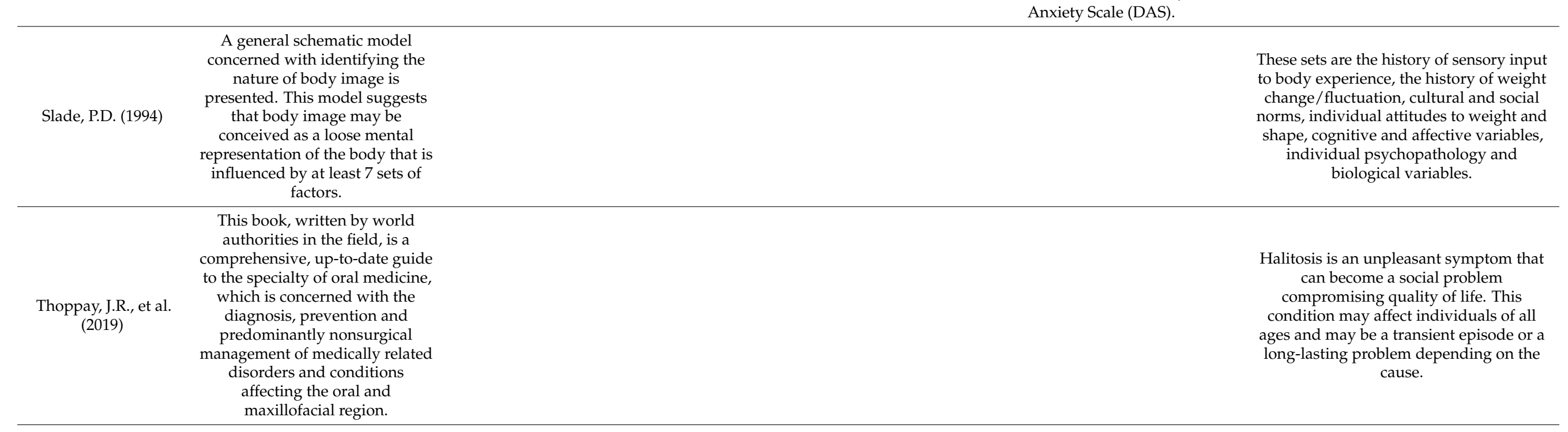


Table 4. Cont.

Publication Aims

The aim of this brief review was to provide information on the

Torales, J., et al

management of oral and dental

patients with mental illness.

Umeizudike,

The aim was to determine the

prevalence of self-reported

halitosis among dental patients

observed in a university hospital.

135 dental patients.

Patients from the Oral

Diagnosis/Periodontology

Clinics of the Lagos University

Teaching Hospital.

The self-administered questionnaire

contained information on age, gender

education, marital status, ethnicity,

religion and self-perception of halitosis.

\section{Results}

The most common oral and dental roblems were analyzed in patients with depression, anxiety, schizophrenia or bipolar dementia, with particula attention to their management.

The prevalence of self-reported halitosis was $14.8 \%$ and was significantly

associated with age 40 years and over and male gender. About $50 \%$ perceived halitosis from themselves, $25 \%$ from family and friends and $20 \%$ from people around them. The majority $(70 \%)$ of patients perceived halitosis from the mouth, 30\% from the mouth and nose. The majority $(75 \%)$ of subjects had perceived halitosis for more than 4 weeks.

The prevalence of halitosis in the

The questionnaire included questions about bad breath and other

The aim of this study was to evaluate the prevalence of halitosis and its associated
790 high school students, aged 14

to 18 ; 484 were boys and 306 were girls.

\section{High school students of} Kermanshah. ssociated factors (demographic

information, background diseases,

oral and dental problems,

decay-missing-filled (DMF) index)

Organoleptic evaluation was
Tanoleptic evaluation was $29.75 \%$ and

higher in boys (32.6\% male vs. $25.2 \%$

female) and $27.47 \%$ in self-perception

(32.9\% male vs. $19 \%$ female). The

diagnostic agreement between

organoleptic and self-perceived halitosis was moderate or poor 
Table 5. Prisma Checklist.

Section/Topic \# Checklist Item Reported on Page \#

Title 1 Adolescence, Adulthood and Self-Perceived Halitosis: A Role of Psychological Factors abstract

Background: Halitosis is a frequent condition that affects a large part of the population. Considered a "social stigma", it can determine a number of psychological and relationship consequences that affect people's lives. The purpose of this review is to examine the role of psychological factors in the condition of self-perceived halitosis in adolescent subjects and adulthood. Type of studies reviewed: We conducted, by the Preferred Reporting Items for Systematic Review and Meta-Analyses (PRISMA) guidelines, systematic research of the literature on PubMed and Scholar. The key terms used were Systematic Review and Meta-Analyses (PRISMA) guidelines, systematic research of the literature on PubMed and Scholar. The key terms used were
halitosis, halitosis self-perception, psychological factors, breath odor and two terms related to sociorelational consequences ("Halitosis and Social Relationship" OR "Social Issue of Halitosis"). Initial research identified 3008 articles. As a result of the inclusion and exclusion criteria, the number of publications was reduced to 38. Results: According to the literature examined, halitosis is a condition that is rarely self-perceived. In general, women have a greater ability to recognize it than men. Several factors can affect the perception of the dental condition, such as socioeconomic status, emotional state and body image. Conclusion and practical implication: Self-perceived halitosis could have a significant impact on the patient's quality of life

Among the most frequent consequences are found anxiety, reduced levels of self-esteem, misinterpretation of other people's attitudes and embarrassment and relational discomfort that often result in social isolation.

\section{introduction}

Halitosis, commonly called bad breath, is a problem that can affect both the external, relational, social communication and internal, psychological sphere, with implications on perceived quality of life [1]. People are usually unaware of their breath, and when they become aware of it, they incorrectly attribute the cause of their condition. Halitosis is a frequent condition, present in 50-65\% of the world population [2]. Although it is a significant source of discomfort, a precise estimation of prevalence is not possible because epidemiological studies are limited. This limitation could be determined by several factors, such as the absence of a standardized method for assessment of the disease, the difficulty in recognizing its presence and the likelihood

Rationale

3 that it is in some cases transient, which is why it is underreported in epidemiological data [3]. The problem of people with halitosis is that this condition can often remain unnoticed because people are generally unaware of the quality of their oral odor. Considered by Kolo [5] as a "social stigma", it could become an obsession that dominates a person's life, determining the onset of factors such as anxiety and psychosocial stress. One theme of studies on self-perceived halitosis shows that the problem is often not self-perceived [20,21]. Self-reported halitosis tends to be underestimated mainly because individuals may have difficulty in detecting their own smell or feel embarrassed to expose themselves, in line with the intimate dimension of the
intentimated individuals may have difficulty in detecting their own smell or feel embarrassed to expose themselves, in line with the intimate dimension of the
relationship with their mouth [22]. Subjects with a good body image pay more attention to their mouth and oral malodor [23]. Recent studies confirm that self-perception of halitosis may be related to a psychogenic or psychosomatic disorder and has a strong psychological impact [31,32].

Objectives

The aim of this work is to examine the role of psychological factors in the condition of self-perceived halitosis in adolescent subjects and adulthood methods

We used the following search terms: halitosis, self-perception halitosis, psychological factors, breath odor and two terms related to sociorelational 5 consequences ("Halitosis and Social Relationship" OR "Social Issue of Halitosis"). In the initial search, we identified 3008 publications; after applying inclusion and exclusion criteria, we analyzed 38 studies. 
Table 5. Cont.

Section/Topic

Eligibility criteria

We used the following eligibility criteria: English language, publication in peer-reviewed scientific journals, quantitative information about

Checklist Item

6 self-perceived halitosis and oral hygiene. Articles were excluded based on title and abstract screen; article type of review article, editorial comment or case report; and year of publication prior to 2010 .

This review was conducted according to Preferred Reporting Items for Systematic Reviews and Meta-Analyses [33]. To identify the studies, we performed a systematic literature search on the PubMed, Scholar and ScienceDirect databases. The search was limited to studies written in English. We identified the literature from January 2010 to January 2020 using four key terms related to self-perceived halitosis, namely halitosis, self-perception

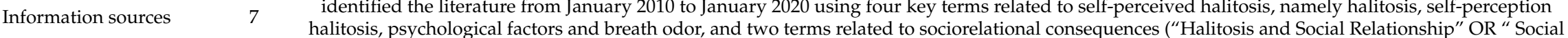
Issue of Halitosis"). The articles from 1994 and 2001 were only cited to introduce the body image theory and to link it to the perception that each individual has of his or her own smell.

Search

Articles were selected by title and abstract: the entire article was read if the title and abstract were related to the specific issue of adolescence, adulthood and self-perceived halitosis and if the article potentially met the inclusion criteria. References of the selected articles were also examined in order to identify additional studies meeting the inclusion criteria.

We performed a systematic literature search on the PubMed, Scholar and ScienceDirect databases. The search was limited to studies written in English.

Study selection

9 We identified the literature from January 2010 to January 2020 using four key terms related to self-perceived halitosis, namely halitosis, self-perception halitosis, psychological factors and breath odor, and two terms related to sociorelational consequences ("Halitosis and Social Relationship" OR "Social Issue of Halitosis").

Data collection process

10

Articles were selected online in relation to the title and abstracts; articles were read in

作

applying the inclusion and exclusion criteria, the total number of relevant publications was reduced to 38.

Data items

11 Not specified.

Across the included studies in this review, a potential database bias should be considered. Only articles written in English language were used, which studies might have compromised access to articles published in other languages.

Summary measures 


\section{Discussion}

The studies analyzed focus on the importance of self-perception of halitosis and the consequences it has on the life of the individual. It is an oral health problem that could be prevented through appropriate oral hygiene practices and to which attention should be paid, given the influence it has on patients' quality of life. The subject's awareness of his or her condition leads to such anxiety that he or she obsessively uses appropriate instruments to eclipse the bad smell, such as sprays, chewing gum, pills or mouthwashes [38]. Although it is a significant condition for the individual, it is not easy to recognize or "self-perceive" it. A study conducted in Saudi Arabia and the United Kingdom [34] showed that 51.9\% of the Saudi population and $54.9 \%$ of the UK population were aware of their halitosis. In contrast, a study conducted on the population of the Netherlands shows that only $4.2 \%$ were able to recognize their bad smell [35]. In individuals with halitosis, certain consequences have a significant impact on the individual. The reduction in self-confidence and self-esteem levels and the onset of depression and stress are the main consequences that can be observed in patients with this condition. The onset of social anxiety is also important, as it could lead the individual to estrangement and avoidance of social interactions. In a study [37], it has been shown that people with halitosis had relationship failures, in particular with individuals of the opposite gender; showed difficulties in achieving their goals; and exhibited compromised performance even in the workplace, considering this condition a "social handicap". The research obtained also allows us to affirm that, although halitosis causes considerable problems in the subject, it is often not treated but ignored or denied. Patients are not very optimistic about treatment. In the literature, it emerges that the self-perception of halitosis could determine the onset of symptoms such as anxiety, obsessive-compulsive disorders and paranoid ideation, and very often subjects misinterpret the attitude of people who relate to them. There is a need to introduce, together with the professional doctor, the intervention of specialists such as psychologists and psychiatrists to prevent consequences $[17,36]$. We believe that it is useful to work in a multidisciplinary mode in which one can intervene on both the oral condition and the psychological conditions of the patient to alter inadequate attitudes and wrong beliefs and to encourage the adoption of behaviors that can reduce the bad smell and improve patients' quality of life.

\section{Limitations}

This study suffers from several limitations: indeed, due to the relatively low number of studies on the topic and their great methodological heterogeneity, a proper formal quality assessment of each work was precluded. Therefore, selection bias was not properly addressed, which can impact the general interpretability of results. In general, care is required when interpreting the results of the cited studies, and further investigations are needed to clarify the relationship between self-perceived and objective halitosis.

\section{Conclusions}

This study has identified the importance of the consequences that the perception of bad breath has on the psychorelational side and, in general, on patients' quality of life. Literature studies have shown that women have, as a percentage, a greater awareness of their dental condition than men. Socioeconomic status is one of the factors that can influence self-perceived halitosis. Research has also led to an understanding of how body image and emotional state may be a variable that can influence perception. Oral hygiene measures can significantly reduce the bad smell. Oral health education must also be provided in many places, including private dental and medical clinics, and it is important that healthcare professionals, including general practitioners and health professionals, understand the etiology and critical factors in order to diagnose and treat patients appropriately. This review has reviewed the studies in the literature. The limitation of our study concerns the exclusive treatment of psychological factors implicated in halitosis at the expense of possible treatments. 
Author Contributions: C.M., A.B., M.R.A.M. and R.A.Z. contributed to conception; design; and data acquisition, analysis and interpretation and drafted and critically revised the manuscript. C.L. contributed to data acquisition, analysis and interpretation and drafted the manuscript. M.M. contributed to data acquisition and drafted the manuscript. M.B.-C., P.J.A.-P. and C.S.F. contributed to conception and critically revised the manuscript. N.I.W. contributed to interpretation and critically revised the manuscript. All authors have read and agreed to the published version of the manuscript.

Funding: This research received no external funding.

Institutional Review Board Statement: Not applicable.

Informed Consent Statement: Not applicable.

Data Availability Statement: The study did not report any data.

Acknowledgments: The authors received no financial support and declare no potential conflicts of interest with respect to the authorship and/or publication of this article.

Conflicts of Interest: The authors declared no potential conflict of interest with respect to the research, authorship and/or publication of this article.

\section{References}

1. Kuzhalvaimozhi, P.; Krishnan, M. Self-Perception, Knowledge and Attitude of Halitosis among patients attending a Dental Hospital in South India-A Questionnaire Based Study. Res. J. Pharm. Technol. 2019, 12, 129. [CrossRef]

2. Schemel-Suárez, M.; Chimenos-Küstner, E.; Estrugo-Devesa, A.; Jané-Salas, E.; López-López, J. Halitosis Assessment and Changes in Volatile Sulfur Compounds after Chewing Gum: A Study Performed on Dentistry Students. J. Évid. Based Dent. Pr. 2017, 17, 381-388. [CrossRef] [PubMed]

3. Thoppay, J.; Filippi, A.; Ciarrocca, K.; Greenman, J.; De Rossi, S. Halitosis. In Contemporary Oral Medicine; Springer: Cham, Switzerland, 2019.

4. Kim, S.Y.; Sim, S.; Kim, S.-G.; Park, B.; Choi, H.G. Prevalence and Associated Factors of Subjective Halitosis in Korean Adolescents. PLoS ONE 2015, 10, e0140214. [CrossRef] [PubMed]

5. Idemudia, A.; Ahmed, A.; Alufohai, O.; Kolo, E. Psychosocial problems in adults with halitosis. J. Med. Trop. 2015, 17, 87. [CrossRef]

6. Settineri, S.; Rizzo, A.; Ottanà, A.; Liotta, M.; Mento, C. Dental aesthetics perception and eating behavior in adolescence. Int. J. Adolesc. Med. Health 2015, 27, 311-317. [CrossRef] [PubMed]

7. Mento, C.; Gitto, L.; Liotta, M.; Muscatello, M.R.A.; Bruno, A.; Settineri, S. Dental anxiety in relation to aggressive characteristics of patients. Int. J. Psychol. Res. 2014, 7, 29-37. [CrossRef]

8. Madhushankari, G.; Yamunadevi, A.; Selvamani, M.; Kumar, K.M.; Basandi, P.S. Halitosis-An overview: Part-I-Classification, etiology, and pathophysiology of halito-sis. J. Pharm. Bioallied Sci. 2015, 7 (Suppl. 2), S339.

9. Azodo, C. Social trait rating of halitosis sufferers: A Crosssectional study. J. Dent. Res. Rev. 2019, 6, 19. [CrossRef]

10. Settineri, S.; Mucciardi, M.; Leonardi, V.; Mallamace, D.; Mento, C. The emotion of disgust in Italian students: A measure of the synthetic disgust index. Int. J. Psychol. Res. 2013, 6, 21-29. [CrossRef]

11. Bin Mubayrik, A.; Al-Hamdan, R.; Al Hadlaq, E.M.; AlBagieh, H.; AlAhmed, D.; Jaddoh, H.; Demyati, M.; Abu Shryei, R. Self-perception, knowledge, and awareness of halitosis among female university students. Clin. Cosmet. Investig. Dent. 2017, 9, 45-52. [CrossRef]

12. Kapoor, U.; Sharma, G.; Juneja, M.; Nagpal, A. Halitosis: Current concepts on etiology, diagnosis and management. Eur. J. Dent. 2016, 10, 292-300. [CrossRef] [PubMed]

13. Özen, M.E.; Aydin, M. Subjective Halitosis: Definition and Classification. J. N. J. Dent. Assoc. 2015, 86, $20-24$.

14. Azodo, C.; Umoh, A. Relational impact of halitosis: A study of young adult Nigerians. Savannah J. Med Res. Pr. 2018, 6, 11. [CrossRef]

15. Colussi, P.R.G.; Hugo, F.N.; Muniz, F.W.M.G.; Rösing, C.K. Oral Health-Related Quality of Life and Associated Factors in Brazilian Adolescents. Braz. Dent. J. 2017, 28, 113-120. [CrossRef] [PubMed]

16. Alsadhan, S.A. Self-perceived halitosis and related factors among adults residing in Riyadh, Saudi Arabia. A cross sectional study. Saudi Dent. J. 2016, 28, 118-123. [CrossRef] [PubMed]

17. Heboyan, A.; Avetisyan, A.; Vardanyan, A. Halitosis as an issue of social and psychological significance. J. Res. Med. Dent. Sci. 2019, 7, 33-40.

18. Mrizak, J.; Ouali, U.; Arous, A.; Jouini, L.; Zaouche, R.; Rebaï, A.; Zalila, H. Successful Treatment of Halitophobia with Cognitive Behavioural Therapy: A Case Study. J. Contemp. Psychother. 2018, 49, 119-125. [CrossRef]

19. Da Conceicao, M.D.; Giudice, F.S.; de Francisco Carvalho, L. The Halitosis Consequences Inventory: Psychometric properties and relationship with social anxiety dis-order. BDJ Open 2018, 4, 1-5. [CrossRef]

20. Dico, G.L. Self-Perception Theory, Radical Behaviourism, and the Publicity/Privacy Issue. Rev. Philos. Psychol. 2017, 9, 429-445. [CrossRef] 
21. Slade, P.D. What is body image? Behav. Res. Ther. 1994, 32, 497-502. [CrossRef]

22. Eli, I.; Baht, R.; Koriat, H.; Rosenberg, M. Self-perception of breath odor. J. Am. Dent. Assoc. 2001, 132, 621-626. [CrossRef] [PubMed]

23. Ashwath, B.; Vijayalakshmi, R.; Malini, S. Self-perceived halitosis and oral hygiene habits among undergraduate dental students. J. Indian Soc. Periodontol. 2014, 18, 357-360. [CrossRef] [PubMed]

24. Settineri, S.; Rizzo, A.; Liotta, M.; Mento, C. Clinical Psychology of Oral Health: The Link Between Teeth and Emotions. SAGE Open 2017, 7, 2158244017728319. [CrossRef]

25. Kisely, S. No Mental Health without Oral Health. Can. J. Psychiatry 2016, 61, 277-282. [CrossRef] [PubMed]

26. Torales, J.; Barrios, I.; González, I.; Barrios, I. Gonz Oral and dental health issues in people with mental disorders. Medwave 2017, 17, e7045. [CrossRef]

27. Adedapo, A.H.; Kolude, B.; Dada-Adegbola, H.O.; Lawoyin, J.O.; Adeola, H.A. Targeted polymerase chain reaction-based expression of putative halitogenic bacteria and volatile sulphur compound analysis among halitosis patients at a tertiary hospital in Nigeria. Odontology 2019, 108, 450-461. [CrossRef]

28. Ziaei, N.; Hosseinpour, S.; Nazari, H.; Rezaei, M.; Rezaei, K. Halitosis And Its Associated Factors Among Kermanshah High School Students (2015). Clin. Cosmet. Investig. Dent. 2019, 11, 327-338. [CrossRef]

29. Goel, S.; Chaudhary, G.; Kalsi, D.; Bansal, S.; Mahajan, D. Knowledge and attitude of indian population toward "self-perceived halitosis". Indian J. Dent. Sci. 2017, 9, 79. [CrossRef]

30. Almas, K.; Smith, S.; Siddiqui, I.; Albaqawi, H.; Almutair, A.; Alzaghran, S.; Almuhanna, L.; Alhumaidan, A.; Alharbi, R. Self-perceived oral malodor, smoking and oral hygiene practices among dental students in the eastern province of saudi arabia. Pak. Oral Dent. J. 2018, 38, 486.

31. Faria, S.F.S.; Costa, F.O.; Silveira, J.O.; Cyrino, R.M.; Cota, L.O.M. Self-reported halitosis in a sample of Brazilians: Prevalence, associated risk predictors and accu-racy estimates with clinical diagnosis. J. Clin. Periodontol. 2020, 47, 233-246. [CrossRef]

32. Settineri, S.; Mento, C.; Gugliotta, S.C.; Saitta, A.; Terranova, A.; Trimarchi, G.; Mallamace, D. Self-reported halitosis and emotional state: Impact on oral conditions and treatments. Health Qual. Life Outcomes 2010, 8, 34. [CrossRef] [PubMed]

33. Moher, D.; Liberati, A.; Tetzlaff, J.; Altman, D.G.; The PRISMA Group. Preferred reporting items for systematic reviews and meta-analyses: The PRISMA statement. PLoS Med. 2009, 6, e1000097. [CrossRef]

34. Bhat, M.Y.S.; Alayyash, A.A. Social stigma related to halitosis in Saudi and British population: A comparative study. J. Dent. Res. Rev. 2016, 3, 65. [CrossRef]

35. De Jongh, A.; van Wijk, A.J.; Horstman, M.; de Baat, C. Self-perceived halitosis influences social interactions. BMC Oral Health 2016, 16, 1-7. [CrossRef] [PubMed]

36. Deolia, S.; Ali, M.; Bhatia, S.; Sen, S. Psychosocial effects of halitosis among young adults. Ann. Indian Psychiatry 2018, 2, 120. [CrossRef]

37. Patel, J.; Kulkarni, S.; Doshi, D.; Reddy, P.; Reddy, S.; Srilatha, A. Association Between Social Anxiety with Oral Hygiene Status and Tongue Coating among Patients with Subjective Halitosis. J. Dent. Hyg. 2017, 91, 55-63. [PubMed]

38. Umeizudike, K.A.; Oyetola, O.E.; Ayanbadejo, P.O.; Alade, G.O.; Ameh, P.O. Prevalence of self-reported halitosis and associated factors among dental patients at-tending a tertiary hospital in Nigeria. Sahel Med. J. 2016, 19, 150. [CrossRef] 